\title{
INFLUENCE OF TOCILIZUMAB ON THE OUTCOME OF PATIENTS WITH COVID-19. RETROSPECTIVE OBSERVATIONAL STUDY
}

\author{
EUGENIA IRENE DAVIDESCU ${ }^{1,2} *$, IRINA ODAJIU ${ }^{1}$, MIRELA DUMITRIT A ILIE ${ }^{1}$, TEODORA $^{1}$, \\ BUNEA $^{1}$, GEORGIANA SANDU ${ }^{1}$, LAURENT IUU STRATAN ${ }^{2,4}$, NICOLETA IFTODE ${ }^{4}$, VICTORIA \\ ARAMA ${ }^{2,4}$, BOGDAN OVIDIU POPESCU ${ }^{1,2,3}$ \\ ${ }^{1}$ Neurology Department, Colentina Clinical Hospital, Bucharest, Romania \\ 2 "Carol Davila" University of Medicine and Pharmacy, Bucharest, Romania \\ ${ }^{3}$ Laboratory of Cell Biology, Neurosciences and Experimental Myology, "Victor Babeș” National Institute of Pathology, \\ Bucharest, Romania \\ 4 “Matei Balș” National Institute of Infectious Diseases, Bucharest, Romania
}

*corresponding author: eugenia.davidescu@umfcd.ro

Manuscript received: August 2020

\begin{abstract}
Cytokine storm seems to be one of the main culprits for developing a severe form of COVID-19, IL-6 being one of its basic components. Therefore, currently, tocilizumab is widely studied as a powerful treatment in patients with severe forms of COVID-19. Our aim was to determine whether it could potentiate a favourable outcome in such patients. We conducted a retrospective observational study including all consecutive admitted patients with confirmed SARS-CoV-2 infection that received treatment with tocilizumab in the period between 01.05-23.08.2020 in "Matei Balș" National Institute for Infectious Diseases and Neurology Department of the Colentina Clinical Hospital in Bucharest, Romania. 22 patients were enrolled with a severe form of COVID-19, predominantly women, with an average age of of $61.72 \pm 14.5$ years. The fatality rate was $31.81 \%$. It was observed that following tocilizumab administration, patients presented improvement in the majority of the studied parameters, statistically significant in the case of fibrinogen, $\mathrm{C}$ reactive protein and blood oxygen level $(\mathrm{p}<0.05)$. Tocilizumab might be regarded as a valuable drug in the management of severe SARS-CoV-2 infection.
\end{abstract}

\section{Rezumat}

Furtuna de citokine pare a fi una dintre principalele cauze pentru dezvoltarea unei forme severe de COVID-19, IL-6 fiind una dintre componentele sale de bază. Prin urmare, în prezent, tocilizumab este studiat pe scară largă ca un tratament la pacienții cu forme severe de COVID-19. Scopul studiului a fost de a determina dacă ar putea potența un rezultat favorabil la astfel de pacienți. S-a realizat un studiu observațional retrospectiv care a inclus toți pacienții internați cu infecție confirmată de SARSCoV-2 care au primit tratament cu tocilizumab în perioada 01.05-23.08.2020 în cadrul Institutului Național pentru Boli Infecțioase „Matei Balș” și al Departamentului de Neurologie al Spitalului Clinic Colentina din București, România. 22 de pacienți au fost înrolați cu o formă severă de COVID-19, predominant femei, cu o vârstă medie de $61,72 \pm 14,5$ ani. Rata mortalității a fost de 31,81\%. S-a observat că, după administrarea tocilizumab, pacienții au prezentat îmbunătățiri în majoritatea parametrilor studiați, semnificativ statistic în cazul fibrinogenului, al concentrației proteinei $\mathrm{C}$ reactive și al nivelului de oxigen din sânge $(\mathrm{p}<0,05)$. Tocilizumab ar putea fi considerat un medicament valoros în gestionarea infecției severe cu SARS-CoV-2.

Keywords: COVID-19, severe form, tocilizumab

\section{Introduction}

The emergence of the "2019 novel coronavirus" or "2019-nCoV", later renamed by the World Health Organization as Severe Acute Respiratory Syndrome Coronavirus 2 (SARS-CoV-2), the etiologic agent of "Coronavirus Disease 2019" (COVID-19), has profoundly changed our lives [29]. In only 8 months since its emergence in the Hubei province of China, SARS-CoV-2 managed to spread all over the world infected over 24 million people and killed more than 830.000 subjects [30]. As reported by the clinical data from Wuhan, China, around $17.7-32.0 \%$ of the patients required admission to Intensive Care Unit
(ICU) and approximately 9.5 - 12.0 days after the first symptoms, some developed multi-organ failure. Therefore, the mortality in patients with severe to critical COVID-19 disease can be as high as 49.0 $61.5 \%$ [27, 29].

Regardless of its name, SARS-CoV-2 infection should be considered a multisystem disease. This is mostly related to the fact that the virus enters the cells by binding with its S1 C-terminal domain of the spike protein to the angiotensin-converting enzyme 2 receptor [30], which is widely spread through the human body lung, stomach, small intestine, colon, skin, lymph nodes, thymus, spleen, liver, kidney, brain, endothelial cells 
and arterial smooth cells [4, 11]. Moreover, it was noticed that "cytokine storm" seems to cause the most severe forms of the disease [18]. Studies imply that SARS-CoV-2 infected patients admitted to ICU had increased serum levels of cytokines such as IL-1 (Interleukin-1), IL-6 (Interleukin-6), IL-7 (Interleukin-7), IL-10 (Interleukin-10), granulocyte-colony stimulating factor, interferon- $\gamma-$ inducible protein, macrophage inflammatory protein $1 \alpha$, monocyte chemoattractant protein and tumour necrosis factor- $\alpha$, which seem to be responsible for the cytokine storm [14].

According to a meta-analysis that included 9 studies, patients with severe COVID-19 exhibit higher serum levels of IL-6 in comparison to those that developed milder forms. Furthermore, on meta-regression it was established that high IL-6 levels are associated with increased fatality. Consequently, IL-6 should be included in a scoring system among other inflammatory biomarkers, in order to readily identify patients that might develop a severe form of COVID-19 [3]. According to a study that compared the mean serum IL-6 level among survivors and non-survivors, a cut-off value of $>80 \mathrm{pg} / \mathrm{mL}$ should be associated with increased mortality risk [8].

Tocilizumab is a recombinant humanized anti-interleukin 6 receptor antibody of the IgG1 subclass [19], that demonstrated efficacy in the management of some autoimmune and inflammatory disorders such as rheumatoid arthritis, systemic juvenile idiopathic arthritis, giant cell arteritis, Castleman's disease, Crohn's disease [13], cytokine release syndrome and neuromyelitis optica $[2,14,21]$. The precautions that need to be taken prior to tocilizumab administration are exclusion of latent tuberculosis (although data from an extended number of clinical trials established that the risk for latent TB reactivation is very low) [6], screening for hepatitis B reactivation (although in short-term use, tocilizumab can cause acute liver failure) [24]; after receiving tocilizumab, patients should be monitored for neutropenia, thrombocytopenia as well as elevated liver enzymes and serum lipids [33]. Hereby we present the results of a retrospective observational study regarding the effect of tocilizumab on the outcome of patients, hypothesizing that it could positively influence it.

\section{Materials and Methods}

\section{Subjects}

In this retrospective observational study were included all patients with confirmed infection with SARSCoV-2 that received treatment with tocilizumab, apart from standard therapy in the period between 01.05.2020 and 23.08.2020, consecutively admitted to "Matei Balș" National Institute for Infectious Diseases or to Neurology Department of the Colentina Clinical Hospital in Bucharest, Romania. Informed consent was obtained from the patients or from a legal representative over the telephone, due to biosafety reasons. The patients were managed according to the internal and the national treatment guidelines corresponding to the aforementioned period, which were timely, updated (www.cnscbt.ro). The study was performed in compliance with the World Medical Association Declaration of Helsinki from 1975.

The recommendation to administer tocilizumab was issued by the infectious disease specialist, in accordance with the patients' condition, in accordance to the national and international treatment guidelines for COVID-19 (4 - $8 \mathrm{mg} / \mathrm{kg}$ bw, 1 to 3 doses, at least 8 to 12 hours apart). Severe forms were considered in patients with evidence of bilateral interstitial pneumonia, low $\mathrm{SaO}_{2}$ (blood oxygen level) requiring supplemental oxygen delivery $+/$ - presence of dyspnoea, progressive inflammatory syndrome as well as increased D-dimer concentrations.

The standard treatment included non-invasive mechanical ventilation: nasal cannula, facial mask or high-flow ventilation according to patients' respiratory requirements, low-molecular-weight heparin in prophylactic or even therapeutic dosage, dexamethasone and a combination of at least two antibiotics (ceftriaxone, linezolid, meropenem, amoxicillin/clavulanic acid, colistin, vancomycin, azithromycin, doxycycline) depending on the patient's clinical and paraclinical parameters. Some patients also received hydroxychloroquine, azithromycin or umifenovir.

Data analysis

Data was collected from the patients' medical records after discharge. It was analysed using Microsoft Excel Data analysis and a $\mathrm{p}$ value $<0.05$ was considered as statistically significant. The primary outcome was patients' evolution, namely the survival rate. We performed Descriptive analysis and t-test for twosamples assuming equal variances. Initial hypothesis was that the duration of symptoms could be negatively correlated with the outcome. We analysed the influence of tocilizumab's administration on patients clinical and paraclinical evolution. We followed the corresponding values of leucocytes, lymphocytes, neutrophils, C reactive protein (CRP), fibrinogen, procalcitonin, ferritin, IL-6, D-dimers, aspartate transaminase (AST), alanine transaminase (ALT), creatinine and $\mathrm{SaO}_{2}-$ measured with a finger pulse oximeter. Blood was drawn using venipuncture in clot activator vacutainer tubes for serum separation, then it was processed in a COBAS 8000 Analyzer or in a VITROS 5.1 FS for biochemistry and in a SYSMEX XN 3000 Analyzer or in a DxH 900 High Volume Lab Hematology Analyzer for complete blood count. The extraction of SARSCoV-2 was performed using an automatic extractor and certified and validated CE-IVD Real Time PCR (polymerase chain reaction) Kits with the CFX 96 Analyzer (GRAL Medical Molecular Biology Laboratory, Bucharest, Romania), respecting the workflow and all necessary conditions with BSL-2 safety level. 
FARMACIA, 2020, Vol. 68, 5

For lacking data, we used the mean values for that parameter.

We also performed a synthetization of the available articles on Pubmed using the "tocilizumab and Covid19 " as searching elements and included the available published or preprint versions of the studies performed since the start of the pandemic.

\section{Results and Discussion}

22 patients with severe COVID-19 were included, with a slightly higher preponderance for women -12 $(54.54 \%)$ and an average age of $61.72 \pm 14.5$ (range: 30 - 88) years. There was a single patient without comorbidities and 5 out of the other 21 did not follow any treatment at home. The type of encountered concomitant pathologies along with their proportion is presented in Table I.

Table I

Patients comorbidities

\begin{tabular}{|l|c|}
\hline \multicolumn{1}{|c|}{ Comorbidity } & Number of patients (\%) \\
\hline Hypertension & $16(72.72 \%)$ \\
\hline Cardiovascular disease & $11(50 \%)$ \\
\hline Obesity & $9(40.9 \%)$ \\
\hline Diabetes mellitus & $7(31.81 \%)$ \\
\hline Dyslipidaemia & $5(22.72 \%)$ \\
\hline $\begin{array}{l}\text { Oncological pathology } \\
\text { (colon cancer, basocelular carcinoma, prostate adenocarcinoma) }\end{array}$ & $5(22.72 \%)$ \\
\hline $\begin{array}{l}\text { Neurological disease } \\
\text { (Parkinson disease, myasthenia gravis, chronic diabetic polyneuropathy) }\end{array}$ & $4(18.18 \%)$ \\
\hline $\begin{array}{l}\text { Inflammatory disease } \\
\text { Previous smokers }\end{array}$ & $3(13.63 \%)$ \\
\hline Chronic kidney disease & $2(9.09 \%)$ \\
\hline $\begin{array}{l}\text { Thrombophilia } \\
\text { Polinodular goiter } \\
\text { Hypersensibility reaction } \\
\text { Active smoking }\end{array}$ & $1(4.05 \%)$ \\
\hline
\end{tabular}

With reference to patients' symptomatology on hospital admission, the percentages are presented in Figure 1. Regarding concomitant neurological symptoms, it is important to mention that 5 patients $(22.72 \%)$ had motor deficit, which was later confirmed to be due to ischemic stroke, 2 patients presented confusion and one patient - an episode of loss of consciousness.

\section{Symptomatology on admission}

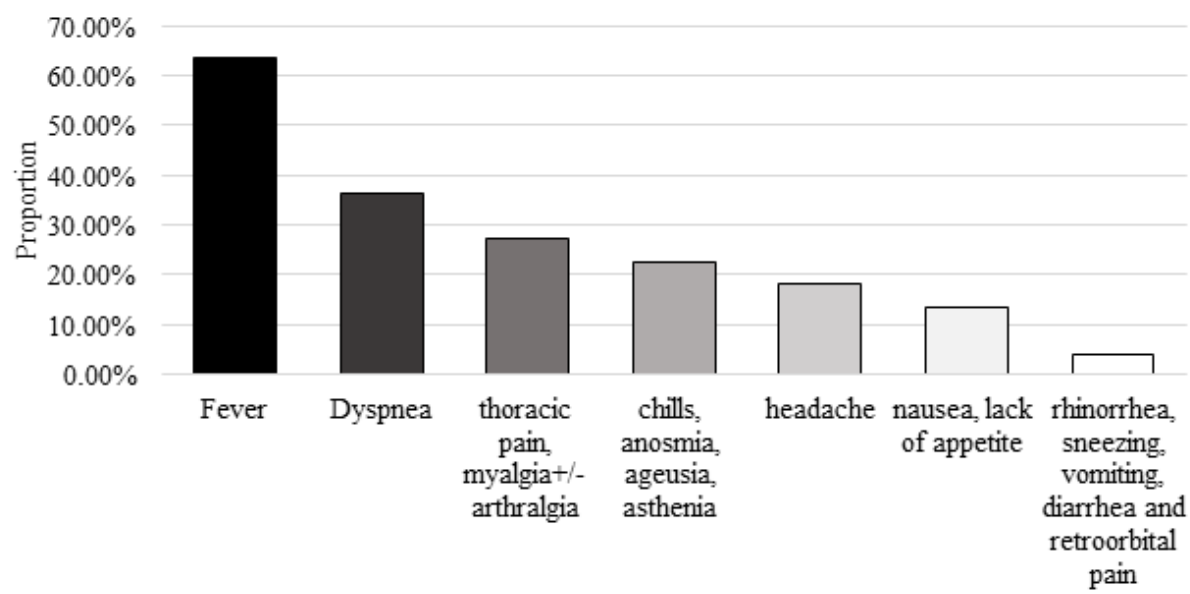

Figure 1.

Patients' symptomatology on admission

Out of the 22 patients enrolled, 7 died during their hospital stay (31.81\%). Speaking about the subjects' biological tests on admission, we have to mention that the majority had lymphopenia, inflammatory syndrome and elevated D-dimers. The average values of these paraclinical parameters are presented in Table II. 


\begin{tabular}{|c|c|c|}
\hline Parameter & Patients with favourable evolution (15) (\% - mean value) & Deceased patients (7) (\% - mean value) \\
\hline Leukocytosis & 0 & $57.14 \%(16885 \times 1000 / \mathrm{mL})$ \\
\hline Lymphopenia & $80 \%(1037.5 \times 1000 / \mathrm{mL})$ & $100 \%(914.28 \times 1000 / \mathrm{mL})$ \\
\hline Neutrophilia & $26.66 \%(8465 \times 1000 / \mathrm{mL})$ & $57.14 \%(15220 \times 1000 / \mathrm{mL})$ \\
\hline Ferritin $\uparrow$ & $46.66 \%(831.46 \mathrm{ng} / \mathrm{mL})$ & $85.71 \%(1202.14 \mathrm{ng} / \mathrm{mL})$ \\
\hline Fibrinogen $\uparrow$ & $53.33 \%(644.12 \mathrm{mg} / \mathrm{dL})$ & $71.42 \%(538.6 \mathrm{mg} / \mathrm{dL})$ \\
\hline $\mathbf{C R P} \uparrow$ & $93.33 \%(49.95 \mathrm{mg} / \mathrm{L})$ & $85.71 \%(111.32 \mathrm{mg} / \mathrm{L})$ \\
\hline D-dimers $\uparrow$ & $18.18 \%(1247.5 \mathrm{ng} / \mathrm{mL})$ & $85.71 \%(8095 \mathrm{ng} / \mathrm{mL})$ \\
\hline $\mathbf{A S T} \uparrow$ & $60 \%(57.88 \mathrm{UI} / \mathrm{mL})$ & $28.57 \%(44.8 \mathrm{UI} / \mathrm{mL})$ \\
\hline $\mathbf{A L T} \uparrow$ & $33.33 \%$ (83.82 UI/L) & 0 \\
\hline Creatinine (mean) & $1.17 \mathrm{mg} / \mathrm{dL}$ & $1.11 \mathrm{mg} / \mathrm{dL}$ \\
\hline $\mathrm{SaO}_{2} \downarrow$ & $60 \%(84.5 \%)$ & $71.42 \%(85 \%)$ \\
\hline
\end{tabular}

$\mathrm{CRP}=\mathrm{C}$ reactive protein; $\mathrm{AST}=$ aspartate transaminase; $\mathrm{ALT}=$ alanine transaminase; $\mathrm{SaO}_{2}-$ blood oxygen level

It has to be outlined that the values for IL-6 were not included in the final analysis, as it was tested in less than half of the patients before and after tocilizumab's administration, we could only mention that it was significantly elevated in $64.28 \%$ of the tested patients with a mean value of $155.48 \pm 244.53$ $\mathrm{pg} / \mathrm{mL}$ and following treatment it dropped to an average of $112.015 \pm 257.29 \mathrm{pg} / \mathrm{mL}$. Regarding procalcitonin, it was tested in only $68.18 \%$ initially with a mean value of $21.05 \pm 9.01 \mathrm{ng} / \mathrm{mL}$ and following treatment with a mean value of $23.64 \pm 11.61 \mathrm{ng} / \mathrm{mL}$. It is also important to mention that all patients required supplemental oxygen delivery from the very start as follows: 3 subjects received oxygen through nasal canula (4 L/min), 11 patients through facial mask (8 $16 \mathrm{~L} / \mathrm{min})$ and 8 required high-flow delivery $(18-30$ $\mathrm{L} / \mathrm{min}$ ), out of which 2 patients were later mechanically ventilated for up to 8 days.

As regards pulmonary imaging, there were identified signs of severe bilateral interstitial pneumonia (involving $>50 \%$ of pulmonary parenchyma) in 10 patients $(45.45 \%)$, moderate in 6 subjects $(27.27 \%)$ (involving between $25-50 \%$ ) and mild also in 6 patients $(27.27 \%)$ (involving $<25 \%$ of pulmonary parenchyma).

The mean duration of hospital stay was $18.54 \pm 9.79$ (range: 3 - 40) days, less for the deceased patients, on average $11.14 \pm 13.03$ days (except one patient -40 days), comparative to those who had a favourable evolution $-21.46 \pm 6.51$ days.

In regard to the patients' evolution following treatment, it is important to outline that there was an improvement in all studied parameters, the most important ones being observed in the case of fibrinogen, CRP as well and in blood oxygen levels that were statistically significant $(\mathrm{p}<0.05)$, for the patients that had a favourable outcome (data presented in Table III).

Table III

Changes in biological parameters

\begin{tabular}{|c|c|c|}
\hline Parameter & Patients with favourable outcome & Deceased patients \\
\hline Fibrinogen & $\downarrow 1.86 \mathrm{x}$ initial mean value $(\mathrm{IMV})(\mathrm{p}<0.001)$ & $\downarrow 1.43 \times \operatorname{IMV}(\mathrm{p}<0.03)$ \\
\hline CRP & $\downarrow 4.66$ x IMV $(\mathrm{p}<0.02)$ & $\downarrow 1.55 \times \operatorname{IMV}(\mathrm{p}<0.23)$ \\
\hline Ferritin & $\uparrow 1.26 \times$ IMV $(p<0.29)$ & $\downarrow 1.09 \times \operatorname{IMV}(\mathrm{p}<0.38)$ \\
\hline $\mathrm{SaO}_{2}$ & $\downarrow 1.07 \times \operatorname{IMV}(\mathrm{p}<0.005)$ & $\downarrow 1.07 \times \operatorname{IMV}(\mathrm{p}<0.16)$ \\
\hline D-dimers & $\downarrow 1.34 \times \operatorname{IMV}(\mathrm{p}<0.25)$ & $\downarrow 1.49 \times \operatorname{IMV}(\mathrm{p}<0.27)$ \\
\hline Lymphocytes & $\uparrow 1.46 \times$ IMV $(p<0.18)$ & $\downarrow 1.06 \times \operatorname{IMV}(\mathrm{p}<0.4)$ \\
\hline Leucocytes & $\uparrow 1.3 \times$ IMV $(p<0.14)$ & $\downarrow 1.07 \times$ IMV $(\mathrm{p}<0.4)$ \\
\hline
\end{tabular}

$\mathrm{CRP}=\mathrm{C}$ reactive protein; $\mathrm{SaO}_{2}-$ blood oxygen level

The extent of time from the appearance of initial symptoms until treatment initiation did not positively influence the outcome, being even larger for patients with a favourable evolution with a mean number of days of $9.46 \pm 3.66$ versus the deceased ones $-6 \pm 1.29$ $(\mathrm{p}<0.02)$. In regard to the total administered dose of tocilizumab, the average values were almost the same $-1949.33 \pm 483.66 \mathrm{mg}$ for patients with a favourable outcome and $1985.71 \pm 758.13 \mathrm{mg}$ for the other ones. Factors that had a more significant influence on the outcome were age, patients with a poor evolution being significantly older $73.85 \pm 8.97$ years, in comparison to those with a favourable outcome $-56.06 \pm 13.02$ years $(\mathrm{p}<0.002)$ and comorbidity: all patients with a poor outcome were hypertensive, $57 \%$ of them were obese and had cardiovascular pathology versus $33.33 \%$ of those with a positive evolution. It is also important to highlight that all presented with severe bilateral pneumonia, low blood oxygen levels, moderate to severe lymphopenia, significant systemic inflammation and a higher concentration of D-dimers since admission.

Concerning the adverse events related to tocilizumab therapy, a significant increase in the values of the ALT ( $<$ 0.02) as well as AST ( $<0.007)$ was 
observed, apparently not correlated with the total administered dose $(r=0.04, \mathrm{p}<0.59)$.

The obtained results of this retrospective observational analysis point to a positive influence of tocilizumab on the outcome of patients with severe COVID-19, the fatality rate being $31.81 \%$. It is necessary to remark that the potential factors influencing the outcome were older age, a greater incidence of comorbidity along with a worse clinical status and a more severe inflammatory syndrome at onset. Our results indicate that tocilizumab therapy could significantly reduce inflammatory markers such as CRP and fibrinogen as well as improve $\mathrm{SaO}_{2}$, reducing the need of supplemental oxygen delivery $(\mathrm{p}<0.05)$. The majority of patients presented bacterial co-infection and superinfection, evaluated using procalcitonin levels and cultures at admission and following tocilizumab usage that demanded antibiotic treatment which could also influence the outcome.

The hypothesis that an earlier administration of tocilizumab could prevent a negative outcome was not supported by our results $(\mathrm{p}<0.02)$, a potential explanation being the small number of included patients, reduced homogeneity among subjects and lack of a control group. Among other biases that could have influenced the results could be mentioned the fact that the patients were from two different institutions, and even if the management was based on the same protocol, the characteristics of the patients, namely age, comorbidities, presentation - were different. With reference to the potential adverse events, namely elevation of liver enzymes, it cannot be excluded that it could be also related to the administration of other concomitant drugs such as combination antibiotic therapy, hydroxychloroquine and dexamethasone.

Our results were in line with the observations made by other studies conducted in this period, presented in Table IV, except for 2 studies according to which there seems to be no positive influence on the patients' outcome [5, 9].

We await the results of larger randomized-control trials in order to fully perceive the efficiency and safety of tocilizumab in COVID-19 patients, that would also respond to the question regarding the proper moment of administration, since an early delivery of tocilizumab might impair the thymocyte differentiation into cytotoxic T cells as well as IgM and IgG production by $\mathrm{B}$ cells which is promoted by IL- 6 and thus could encourage viral replication [28]. On the other hand, a late tocilizumab administration might be totally ineffective [22].

Table IV

Effectiveness of tocilizumab in patients with COVID-19

\begin{tabular}{|c|c|c|c|c|}
\hline Article & Type of study & $\begin{array}{c}\text { Number of } \\
\text { patients }\end{array}$ & Other treatments & Outcome \\
\hline $\begin{array}{c}{[26]} \\
\text { Effective treatment of } \\
\text { severe COVID-19 } \\
\text { patients with tocilizumab }\end{array}$ & $\begin{array}{l}\text { Observational } \\
\text { retrospective } \\
\text { study (China) }\end{array}$ & 21 & Lack of data & $\begin{array}{l}\text { Improvement of respiratory function, } \\
\text { normalization of lymphocyte count, } \\
\text { reduction in CRP values and lung } \\
\text { opacities in } 90.5 \%\end{array}$ \\
\hline \begin{tabular}{|c|}
{$[15]$} \\
J Med Virol., $2020 \mathrm{Jul}$ \\
92(7): 814-818.
\end{tabular} & $\begin{array}{l}\text { Retrospective } \\
\text { observational } \\
\text { study (China) }\end{array}$ & 15 & Methylprednisolone & $\begin{array}{l}4 \text { out } 7 \text { patients aggravated or died } \\
\text { regardless of a decrease in CRP values; }\end{array}$ \\
\hline $\begin{array}{c}1] \\
\text { J Med Virol., } 2020 \text { May }\end{array}$ & $\begin{array}{l}\text { Retrospective } \\
\text { study (Qatar) }\end{array}$ & 25 & $\begin{array}{l}\text { Lopinavir/ritonavir, } \\
\text { ribavirin and/or interferon } \\
\text { alpha 2-a, hydroxy- } \\
\text { chloroquine, azithromycin }\end{array}$ & $\begin{array}{l}\text { Amelioration of the respiratory function, } \\
\text { reduction of the level of inflammatory } \\
\text { markers, radiological improvement }\end{array}$ \\
\hline $\begin{array}{c}{[7]} \\
\text { Eur J Intern Med., } 2020 \\
\quad \text { Jun; 76: 31-35 }\end{array}$ & $\begin{array}{l}\text { Preliminary } \\
\text { results of a non- } \\
\text { randomized } \\
\text { prospective } \\
\text { study (Italy) } \\
\end{array}$ & 25 & $\begin{array}{l}\text { Hydroxychloroquine, } \\
\text { lopinavir/ritonavir }\end{array}$ & $\begin{array}{c}\% \text { of patients treated with tocilizumab who } \\
\text { completely recovered and had a more } \\
\text { positive clinical course, was higher compared } \\
\text { to those who underwent only standard } \\
\text { therapy ( } 92 \% \text { to } 42.1 \% \text { respectively) }\end{array}$ \\
\hline $\begin{array}{c}{[25]} \\
\text { Autoimmun Rev., } 2020 \\
\text { Jul; 19(7): } 102568\end{array}$ & $\begin{array}{l}\text { Prospective } \\
\text { multicentre } \\
\text { study (Italy) }\end{array}$ & 100 & $\begin{array}{c}\text { Lopinavir/ritonavir or } \\
\text { remdesivir, antibiotics } \\
\text { (azithromycin, ceftriaxone } \\
\text { or piperacillin/tazobactam), } \\
\text { hydroxychloroquine and } \\
\text { dexamethasone }\end{array}$ & $\begin{array}{c}\text { A rapid sustained response at } 24-72 \mathrm{~h} \\
\text { following drug administration in around } \\
70 \% \text { of the patients and at } 10 \text { days, a } \\
\text { substantial clearance of pulmonary lesions } \\
\text { on chest X-ray }\end{array}$ \\
\hline $\begin{array}{c}{[9]} \\
\text { Microorganisms, } 2020 \\
\text { May 9; 8(5): } 695\end{array}$ & \begin{tabular}{|} 
Preliminary \\
results from the \\
SMAtteo \\
COvid19 \\
REgistry \\
(SMACORE) \\
(Italy)
\end{tabular} & 21 & $\begin{array}{l}\text { Hydroxychloroquine, } \\
\text { azithromycin, low } \\
\text { weight heparin - } \\
\text { prophylactic dose }\end{array}$ & $\begin{array}{l}\text { Tocilizumab administration did not reduce } \\
\text { ICU admission or mortality rate }\end{array}$ \\
\hline
\end{tabular}


FARMACIA, 2020, Vol. 68, 5

\begin{tabular}{|c|c|c|c|c|}
\hline Article & Type of study & $\begin{array}{c}\text { Number of } \\
\text { patients }\end{array}$ & Other treatments & Outcome \\
\hline $\begin{array}{c}{[5]} \\
\text { Eur J Intern Med., } 2020 \\
\text { Jun; 76: 43-49 }\end{array}$ & $\begin{array}{l}\text { Single-centre } \\
\text { retrospective } \\
\text { cohort study } \\
\quad \text { (Italy) }\end{array}$ & 32 & $\begin{array}{l}\text { Hydroxychloroquine, } \\
\text { lopinavir/ritonavir, }\end{array}$ & $\begin{array}{l}\text { No statistical difference regarding clinical } \\
\text { amelioration and mortality at day } 28\end{array}$ \\
\hline $\begin{array}{c}{[16]} \\
\text { Effects of tocilizumab on } \\
\text { Mortality in Hospitalized } \\
\text { Patients with COVID-19: } \\
\text { A Multi-center Cohort } \\
\text { Study } \\
\end{array}$ & $\begin{array}{l}\text { Multi-centre } \\
\text { cohort study } \\
\text { (Spain) }\end{array}$ & 260 & $\begin{array}{l}\text { Corticosteroids, } \\
\text { hydroxychloroquine, } \\
\text { azithromycin, } \\
\text { lopinavir/ritonavir }\end{array}$ & $\begin{array}{l}66 \% \text { reduction of mortality risk in subjects } \\
\text { with baseline CRP levels }>150 \mathrm{mg} / \mathrm{L} \text { who } \\
\text { received tocilizumab }\end{array}$ \\
\hline $\begin{array}{l}\text { [17] } \\
\text { Tocilizumab and steroid } \\
\text { treatment in patients with } \\
\text { COVID-19 pneumonia }\end{array}$ & $\begin{array}{l}\text { Observational } \\
\text { single-centre } \\
\text { study (Italy) }\end{array}$ & 130 & $\begin{array}{l}\text { Hydroxychloroquine, } \\
\text { darunavir/ritonavir, +/- } \\
\text { methylprednisolone }\end{array}$ & $\begin{array}{c}\text { Patients with tocilizumab+/- methyl- } \\
\text { prednisolone had a higher failure-free } \\
\text { survival } 80.8 \% \text { versus those without } 64.1 \% \\
\text { and higher overall survival } 85.9 \% \text { vs. } 71.9 \%\end{array}$ \\
\hline $\begin{array}{c}\text { [20] } \\
\text { Tocilizumab for patients } \\
\text { with COVID-19 } \\
\text { pneumonia. The } \\
\text { TOCIVID-19 prospective } \\
\text { phase } 2 \text { trial } \\
\end{array}$ & $\begin{array}{l}\text { Multi-centre } \\
\text { single-arm, } \\
\text { hypothesis- } \\
\text { driven phase } 2 \\
\text { trial (Italy) }\end{array}$ & 180 & $\begin{array}{l}\text { Antiviral treatment, } \\
\text { corticosteroids }\end{array}$ & $\begin{array}{c}\text { Reduced lethality rate at } 30 \text { days with no } \\
\text { significant toxicity }\end{array}$ \\
\hline $\begin{array}{c}\text { [24] } \\
\text { Tocilizumab for treatment } \\
\text { of mechanically } \\
\text { ventilated patients with } \\
\text { COVID-19 } \\
\end{array}$ & $\begin{array}{l}\text { Single-centre } \\
\text { cohort study } \\
\text { (USA) }\end{array}$ & 78 & $\begin{array}{l}\text { Hydroxychloroquine } \\
\text { initially, later it was } \\
\text { removed from protocol } \\
\text { and remdesivir given+/- } \\
\text { corticosteroids }\end{array}$ & $\begin{array}{l}\text { Treatment was associated with a decreased } \\
\text { fatality likelihood, but an increased rate of } \\
\text { superinfection }\end{array}$ \\
\hline \begin{tabular}{c|}
{$[10]$} \\
Lancet Rheumatol., \\
2020; 2: e474-e484
\end{tabular} & $\begin{array}{l}\text { Retrospective } \\
\text { observational } \\
\text { cohort study } \\
\text { (Italy) }\end{array}$ & 179 & $\begin{array}{l}\text { Hydroxychloroquine, } \\
\text { azithromycin, } \\
\text { lopinavir/ritonavir or } \\
\text { darunavir-cobicistat } \\
\end{array}$ & $\begin{array}{l}\text { Reduced risk of invasive mechanical } \\
\text { ventilation or death }\end{array}$ \\
\hline
\end{tabular}

\section{Conclusions}

Given that there is no standard gold therapy for SARS-CoV-2 infection, tocilizumab might be regarded as a valuable drug for the patients with this new disease, positively influencing the outcome, especially by reducing the inflammatory syndrome and improving blood oxygen level.

\section{Conflict of interest}

The authors declare no conflict of interest.

\section{References}

1. Alattar R, Ibrahim TBH, Shaar SH, Abdalla S, Shukri K, Daghfal JN, Khatib MY, Aboukamar M, Abukhattab M, Alsoub HA, Almaslamani MA, Omrani AS, Tocilizumab for the treatment of severe coronavirus disease 2019. J Med Virol., 2020; 1-8.

2. Araki M, Matsuoka T, Miyamoto K, Kusunoki S, Okamoto T, Murata M, Miyake S, Aranami T, Efficacy of the anti-IL-6 receptor antibody tocilizumab in neuromyelitis optica: a pilot study. Neurology, 2014; 82(15): 1302-1306.

3. Aziz M, Fatima R, Assaly R, Elevated interleukin-6 and severe COVID-19: A meta-analysis. J Med Virol., 2020; 92(11): 2283-2285.

4. Blejan IE, Diaconu CC, Arsene AL, Udeanu DI, Ghica M, Drăgănescu D, Burcea Dragomiroiu GTA, Rădulescu M, Maltezou HC, Tsatsakis AM, Papasavva M, Drakoulis N, Popa DE, Antibiotic resistance in community-acquired pneumonia. A Romanian perspective. Farmacia, 2020; 68(3): 512-520.

5. Campochiaro C, Della-Torre E, Cavalli G, De Luca G, Ripa M, Boffini N, Tomelleri A, Baldissera E, Rovere-Querini P, Ruggeri A, Monti G, De Cobelli F, Zangrillo A, Tresoldi M, Castagna A, Dagna L, Group TRS, Efficacy and safety of tocilizumab in severe COVID-19 patients: a single-centre retrospective cohort study. Eur J Intern Med., 2020; 76: 43-49.

6. Cantini F, Nannini C, Niccoli L, Petrone L, Ippolito G, Goletti D, Risk of Tuberculosis Reactivation in Patients with Rheumatoid Arthritis, Ankylosing Spondylitis, and Psoriatic Arthritis Receiving NonAnti-TNF-Targeted Biologics. Mediators Inflamm., 2017; 2017: Art. ID 8909834: 1-15.

7. Capra R, De Rossi N, Mattioli F, Romanelli G, Scarpazza C, Sormani MP, Cossi S, Impact of low dose tocilizumab on mortality rate in patients with COVID-19 related pneumonia. Eur J Intern Med., 2020; 76: 31-35.

8. Chen T, Wu D, Chen H, Yan W, Yang D, Chen G, Ma K, Xu D, Yu H, Wang H, Wang T, Guo W, Chen J, Ding C, Zhang X, Huang J, Han M, Li S, Luo X, Zhao J, Ning Q, Clinical characteristics of 113 deceased patients with coronavirus disease 2019: retrospective study. $B M J, 2020 ; 368: \mathrm{m} 1091:$ 1-25.

9. Colaneri M, Bogliolo L, Valsecchi P, Sacchi P, Zuccaro V, Brandolino F, Montecucco C, Mojoli F, Giusti EM, Bruno R, The Covid Irces San Matteo Pavia Task Force, Tocilizumab for Treatment of Severe COVID-19 Patients: Preliminary Results from SMAtteo 
COvid19 REgistry (SMACORE). Microorganisms, 2020; 8(5): 695: 1-12.

10. Guaraldi G, Meschiari M, Cozzi-Lepri A, Milic J, Tonelli R, Menozzi M, Franceschini E, Cuomo G, Orlando G, Borghi V, Santoro A, Di Gaetano M, Puzzolante C, Carli F, Bedini A, Corradi L, Fantini R, Castaniere I, Tabbì L, Girardis M, Tedeschi S, Giannella M, Bartoletti M, Pascale R, Dolci G, Brugioni L, Pietrangelo A, Cossarizza A, Pea F, Clini E, Salvarani C, Massari M, Viale PL, Mussini C, Tocilizumab in patients with severe COVID-19: a retrospective cohort study. Lancet Rheumatol., 2020; 2(8): e474-e484.

11. Hamming I, Timens W, Bulthuis MLC, Lely AT, Navis GJ, van Goor H, Tissue distribution of ACE2 protein, the functional receptor for SARS coronavirus. A first step in understanding SARS pathogenesis. $J$ Pathol., 2004; 203(2): 631-637.

12. Huang $\mathrm{C}$, Wang $\mathrm{Y}, \mathrm{Li} \mathrm{X}$, Ren $\mathrm{L}$, Zhao J, Hu Y, Zhang L, Fan G, Xu J, Gu X, Cheng Z, Yu T, Xia J, Wei Y, Wu W, Xie X, Yin W, Li H, Liu M, Xiao Y, Gao H, Guo L, Xie J, Wang G, Jiang R, Gao Z, Jin Q, Wang J, Cao B, Clinical features of patients infected with 2019 novel coronavirus in Wuhan, China. Lancet (London, England), 2020; 395(10223): 497-506.

13. Ito H, Takazoe M, Fukuda Y, Hibi T, Kusugami K, Andoh A, Matsumoto T, Yamamura T, Azuma J, Nishimoto N, Yoshizaki K, Shimoyama T, Kishimoto $\mathrm{T}$, A pilot randomized trial of a human antiinterleukin-6 receptor monoclonal antibody in active Crohn's disease. Gastroenterol., 2004; 126(4): 989-996.

14. Le RQ, Li L, Yuan W, Shord SS, Nie L, Habtemariam BA, Przepiorka D, Farrell AT, Pazdur R, FDA Approval Summary: Tocilizumab for Treatment of Chimeric Antigen Receptor T Cell-Induced Severe or Life-Threatening Cytokine Release Syndrome. Oncologist, 2018; 23(8): 943-947.

15. Luo P, Liu Y, Qiu L, Liu X, Liu D, Li J, Tocilizumab treatment in COVID-19: A single center experience. J Med Virol., 2020; 92(7): 814-818.

16. Martinez-Sanz J, Muriel A, Ron R, Herrera S, Ron R, Perez-Molina JA, Moreno S, Serrano-Villar S, Effects of Tocilizumab on Mortality in Hospitalized Patients with COVID-19: A Multicenter Cohort Study. Clin Microbiol Infect., 2020; (23): 1-19.

17. Mikulska M, Nicolini LA, Signori A, Di Biagio A, Sepulcri C, Russo C, Dettori S, Berruti M, Sormani MP, Giacobbe DR, Vena A, De Maria A, Dentone C, Taramasso L, Mirabella M, Magnasco L, Mora S, Delfino E, Toscanini F, Balletto E, Alessandrini AI, Baldi F, Briano F, Camera M, Dodi F, Ferrazin A, Labate L, Mazzarello G, Pincino R, Portunato F, Tutino S, Barisione E, Bruzzone B, Orsi A, Schenone E, Rosseti N, Sasso E, Da Pelosi P, Beltramini S, Giacomini M, Icardi G, Gratarola A, Bassetti M, Tocilizumab and steroid treatment in patients with severe Covid-19 pneumonia. PLoS One, 2020; 15(8): e0237831: 1-16.

18. Moore JB, June $\mathrm{CH}$, Cytokine release syndrome in severe COVID-19. Science, 2020; 368(6490): 473-474.

19. Nanshan Chen, Min Zhou, Xuan Dong, Jieming Qu, Fengyun Gong, Yang Han, Yang Qiu, Jingli Wang, Ying Lin, Yuan Wei, Jia'an Xia, Ting Yu, Xinxin Zhang, Epidemiological and clinical characteristics of 99 cases of 2019 novel coronavirus pneumonia in Wuhan, China: a descriptive study. Lancet, 2020, 395(10223): 507-513.

20. Perrone F, Piccirillo MC, Ascierto PA, Salvarani C, Parrella R, Marata AM, Popoli P, Ferraris L, Marrocco Trischitta MM, Ripamonti D, Binda F, Bonfanti P, Squillace N, Castelli F, Muiesan ML, Lichtner M, Calzetti C, Salerno ND, Atripaldi L, Cascella M, Massimo C, Dolci G, Facciolongo NC, Fraganza F, Massari M, Montesarchio V, Mussini C, Negri EA, Cardone C, Gargiulo P, Gravina A, Schettino C, Arenare L, Chiodini P, Gallo C, Tocilizumab for patients with COVID-19 pneumonia. The TOCIVID19 prospective phase 2 trial. Contemp Clin Trials, Elsevier, ahead of print, 2020; 1-24.

21. Oldfield V, Dhillon S, Plosker GL, Tocilizumab: a review of its use in the management of rheumatoid arthritis. Drugs, 2009; 69(5): 609-632.

22. Radbel J, Narayanan N, Bhatt PJ, Use of Tocilizumab for COVID-19-Induced Cytokine Release Syndrome: A Cautionary Case Report. Chest, 2020; 158(1): e15e19.

23. Schiff MH, Kremer JM, Jahreis A, Vernon E, Isaacs JD, van Vollenhoven RF, Integrated safety in tocilizumab clinical trials. Arthritis Res Ther., 2011; 13(5): R141: $1-13$.

24. Somers EC, Eschenauer GA, Troost JP, Golob JL, Gandhi TN, Wang L, Zhou N, Petty LA, Bang JH, Dillman NO, Frame D, Gregg KS, Kaul DR, Nagel J, Patel TS, Zhou S, Lauring AS, Hanauer DA, Martin E, Sharma P, Fung CM, Pogue JM, Tocilizumab for treatment of mechanically ventilated patients with COVID-19. Clin Infect Dis., 2020; 11: 1-24.

25. Toniati P, Piva S, Cattalini M, Garrafa E, Regola F, Castelli F, Franceschini F, Airò P, Bazzani C, Beindorf EA, Berlendis M, Bezzi M, Bossini N, Castellano M, Cattaneo S, Cavazzana I, Contessi GB, Crippa M, Delbarba A, De Peri E, Faletti A, Filippini M, Filippini M, Frassi M, Gaggiotti M, Gorla R, Lanspa M, Marino R, Maroldi R, Metra M, Matteelli A, Modina D, Moioli G, Montani G, Muiesan ML, Odolini S, Peli E, Pesenti S, Pezzoli MC, Pirola I, Pozzi A, Proto A, Rasulo FA, Renisi G, Ricci C, Rizzoni D, Romanelli G, Rossi M, Salvetti M, Scolari F, Signorini L, Taglietti M, Tomasoni G, Tomasoni LR, Turla F, Valsecchi A, Zani D, Zuccalà F, Zunica F, Focà E, Andreoli L, Latronico N, Tocilizumab for the treatment of severe COVID-19 pneumonia with hyperinflammatory syndrome and acute respiratory failure: A single center study of 100 patients in Brescia, Italy. Autoimmun Rev., 2020; 19(7): 102568: 1-7.

26. Xu X, Han M, Li T, Sun W, Wang D, Fu B, Zhou Y, Zheng X, Yang Y, Li X, Zhang X, Pan A, Wei H, Effective treatment of severe COVID-19 patients with tocilizumab. Proc Natl Acad Sci USA, 2020; 117(20): 10970-10975.

27. Xiaobo Yang, Yuan Yu, Jiqian $\mathrm{Xu}$, Huaqing Shu, Jia'an Xia, Hong Liu, Yongran Wu, Lu Zhang, Zhui Yu, Minghao Fang, Ting Yu, Yaxin Wang, Shangwen Pan, Xiaojing Zou, Shiying Yuan, You Shang, Clinical course and outcomes of critically ill patients with SARS-CoV-2 pneumonia in Wuhan, China: a single centered, retrospective, observational study. Lancet Respir Med (London, England), 2020; 8(5): 475-481. 
28. Zhang C, Wu Z, Li JW, Zhao H, Wang GQ, Cytokine release syndrome in severe COVID-19: interleukin6 receptor antagonist tocilizumab may be the key to reduce mortality. Int J Antimicrob Agents, 2020; 55(5): 105954: 1-7.

29. Epidemiology Working Group for NCIP Epidemic Response, Chinese Center for Disease Control and Prevention The epidemiological characteristics of an outbreak of 2019 novel coronavirus diseases (COVID19) in China. Zhonghua Liu Xing Bing Xue Za Zhi, 2020; 41(2): 145-151, (available in Chinese).

30. Zhou P, Yang XL, Wang XG, Hu B, Zhang L, Zhang W, Si HR, Zhu Y, Li B, Huang CL, Chen HD, Chen J, Luo Y, Guo H, Jiang RD, Liu MQ, Chen Y, Shen
XR, Wang X, Zheng XS, Zhao K, Chen QJ, Deng F, Liu LL, Yan B, Zhan FX, Wang YY, Xiao GF, Shi ZL, A pneumonia outbreak associated with a new coronavirus of probable bat origin. Nature, 2020; 579(7798): 270-273.

31. *** WHO, www.who.int/dg/speeches/detail/whodirector-general-s-remarks-at-the-media-briefingon-2019-ncov-on-11-february-2020.

32. *** University, J. H., Coronavirus Resource Center, 2020, https://coronavirus.jhu.edu/map.html.

33. *** www.ema.europa.eu/en/documents/productinformation/roactemra. 